\title{
Engineering Properties of Groundnut Pods and Kernels: A Key Role for Designing the Post-harvest Processing Equipment
}

\author{
Vinod Choudhary*, Rajendra Machavaram, Vikas and Ravi Shankar Singh \\ Agricultural and Food Engineering Department, Indian Institute of Technology, \\ Kharagpur, West Bengal-721302, India \\ *Corresponding author
}

\begin{tabular}{|c|c|}
\hline & A B S T R A C T \\
\hline Keywords & \multirow{9}{*}{$\begin{array}{l}\text { Some physical and mechanical properties of the groundnut pods and kernels were } \\
\text { measured. The main motive of this study to provide a summary of the engineering } \\
\text { properties of the TAG- } 24 \text { variety of the groundnut pods and kernels. The average } \\
\text { values of the geometric diameter, surface area, sphericity, angle of repose, and } \\
\text { coefficient of friction were found to be } 16.93 \mathrm{~mm}, 906.01 \mathrm{~mm}^{2}, 48.95 \%, 24.20^{\circ} \text {, and } \\
0.41 \text {, respectively at moisture content of } 6.82 \%(\mathrm{db}) \text { for the groundnut pods. } \\
\text { Furthermore, the average values of the geometric diameter, surface area, sphericity, } \\
\text { angle of repose, and coefficient of friction were found as } 8.65 \mathrm{~mm}, 237.03 \mathrm{~mm}^{2} \text {, } \\
71.94 \%, 20.43^{\circ} \text { and } 0.43 \text {, respectively at moisture content of } 5.02 \% \text { (db) for the } \\
\text { groundnut kernels. The energy required to crush the groundnut pods was determined } \\
\text { as } 1.88 \mathrm{~kJ} / \mathrm{kg} \text { for particular TAG- } 24 \text { groundnut variety. The mean rupture force for the } \\
\text { shelling of groundnut pods was measured by keeping the pods on the test bench } \\
\text { longitudinally, laterally and vertically; the rupture force was found to be } 62.37 \mathrm{~N} \text {, } \\
250.21 \mathrm{~N} \text { and } 32.74 \mathrm{~N} \text { respectively. }\end{array}$} \\
\hline Engineering & \\
\hline $\begin{array}{l}\text { properties, } \\
\text { Groundnut pods, } \\
\text { Groundnut kernels }\end{array}$ & \\
\hline & \\
\hline & \\
\hline Article Info & \\
\hline $\begin{array}{l}\text { Accepted: } \\
18 \text { July } 2020\end{array}$ & \\
\hline & \\
\hline & \\
\hline
\end{tabular}

\section{Introduction}

Groundnut (Arachis hypogaea L.) is an important oilseed crop in our country, and it is generally used for food and feed. Worldwide, it occupies the sixth rank in oilseed crops, and developing countries contribution $97 \%$ of cultivation area and produces $94 \%$ of the groundnut pods (Shubham, 2015). In India, the groundnut is grown around 4.91 million hectares, with the second position of production 9.18 million tones after China. India's five states, Gujarat, Rajasthan, Andhra
Pradesh, Tamil Nadu, and Karnataka, cover around $82 \%$ of groundnut cultivation with the highest production $85 \%$. Among these major producing states, Gujarat has the most top production of $42.88 \%$ from a total share of cultivation area $34.18 \%$ (Anon., 2018). Groundnut kernels have various utilizations viz., peanut butter, and edible oil. The edible oil used extensively not only for cooking but also in making soaps and cosmetics. The residual oilcake contains $7-8 \%$ of $\mathrm{N}, 1.5 \%$ of $\mathrm{P}_{2} \mathrm{O}_{5}$, and $1.2 \%$ of $\mathrm{K}_{2} \mathrm{O}$ used as a fertilizer and it can be used as a fodder for livestock 
(Putnam et al., 2013). In the world, almost $67 \%$ of groundnut pods crushed for edible oil and $33 \%$ used for food and its kernel contains $40-50 \%$ fat, $20-50 \%$ protein, $10-20 \%$ carbohydrate and $43-55 \%$ edible oil depending upon variety and agronomic conditions of the groundnut (Akcali et al., 2006; Okello et al., 2010).

In spite of the financial probable of groundnut pods, the post-harvest processing operations are mainly completed manually. A lot of time and laborious are needed in post-harvest processing operations, implicit unhygienic situations and output can be found with more broken of kernels of shelling of groundnut pods. Hence, a brief intellectuality of engineering properties of groundnut pods and kernels are played an important role in designing of agricultural harvesting and postharvest processing units viz., shelling unit, sieve unit, conveying, cleaning, delivering, separation, packing, sorting, drying, mechanical oil expelling and handling (Davies, 2009; Mohsenin, 1986). Most of the agriculture machines engaged in harvesting and post-harvest processing of groundnut pods are available without considering the design parameters of the groundnut pods and kernels' engineering properties. Hence, a large amount of the output efficiency reduced and increases the losses from these machines (Manuwa and Afuye, 2004; Razariet al., 2007). The physical properties of groundnut pods and kernels do not only build the general engineering data desired for machines and implement design, but also give the brief knowledge for choose the proper methods for receiving those data (Singh et al., 1983).

Many of the researchers suggested only the physical properties of the groundnut kernels. Agarwal et al., (1973) described the shapes of the one or two hulled peanuts as an ellipsoid, double ellipsoid, and cassinoid. Olajide and Igbeka, (2003) measured the size of peanuts.
They were found mean major, intermediate, and minor diameters of the kernels as 8.54, 3.55 , and $6.93 \mathrm{~mm}$, respectively. It was also determined the angle of repose of kernels as $17^{\circ}$. Kaleemullah (1992) explained the variation in dimensions of groundnut kernels with moisture content. Still, the researchers have concentrated only on the groundnut kernels. Therefore, this study's motive was to describe the brief knowledge for the engineering properties of the groundnut pods and kernels for proper designing of agriculture equipment.

\section{Materials and Methods}

\section{Physical Properties of Groundnut Pods and Kernels}

A $10 \mathrm{~kg}$ local cultivar TAG 24 variety of groundnut pods were procured from the local farmers of Paschim Medinipur, West Bengal. The engineering properties of groundnut pods and kernels were measured at the Agricultural and Food Engineering Department, Indian Institute of Technology Kharagpur, West Bengal, India. The moisture content of groundnut pods was determined using the ASAE (1983) method by the hot oven dryer at $103^{\circ} \mathrm{C}$ for 72 hours (Koushkaki et al., 2017), and it was found to be $9.82 \%(\mathrm{db})$.

\section{Determination of the size of the groundnut pods and kernels}

One hundred groundnut kernels and pods were randomly selected, and their three principal dimensions (Fig. 1 and 2) were measured using digital Vernier caliper with $0.01 \mathrm{~mm}$ accuracy. The geometric mean diameter $\left(D_{g}\right)$, sphericity $\left({ }^{\phi}\right)$, surface area $(S)$ and aspect ratio $\left({ }^{R_{a}}\right)$ were calculated by using Equations (1), (2), (3) and (4), respectively given by (Mohsenin, 1986; McCabe et al., 1986). 
$\mathrm{D}_{\mathrm{E}}=(\mathrm{LWT})^{\frac{1}{\mathrm{a}}}$

$\phi=\frac{(\mathrm{LWT})^{\frac{1}{\mathrm{a}}}}{\mathrm{L}} \times 100$

$\mathrm{S}=\pi \mathrm{D}_{\mathrm{g}}^{2}$

$\mathrm{R}_{\mathrm{a}}=\frac{\mathrm{w}}{\mathrm{L}} \times 100$

Where, $\mathrm{D}_{\mathrm{g}}=$ geometric mean diameter $(\mathrm{mm})$; $\mathrm{L}=$ length $(\mathrm{mm}) ; \mathrm{W}=$ width $(\mathrm{mm})$ and $\mathrm{T}=$ thickness $(\mathrm{mm}) ; \phi=$ sphericity $(\%) ; \mathrm{S}=$ surface area $\left(\mathrm{mm}^{2}\right)$ and $\mathrm{R}_{\mathrm{a}}=$ aspect ratio $(\%)$

Determination of average weight of the groundnut pods and kernels

A sample of 1000 groundnut pods and kernels was selected randomly to determine the average weight at moisture content of $6.82 \%$ and $5.02 \%(\mathrm{db})$, respectively, using a digital balance with the accuracy of $0.01 \mathrm{~g}$. The experiments were replicated five times to minimize the error.

\section{Determination of bulk density of the groundnut pods and kernels}

A sample of kernels and pods with known mass (56 g) was poured into a container of volume $(500 \mathrm{ml})$ at a constant rate. The bulk density $\left(\mathrm{kg} / \mathrm{m}^{3}\right)$ of groundnut pods and kernels were measured using the AOAC (1980) method from the mass of groundnut pods and kernels divided by the occupied volume of the groundnut pods and kernels in the container as using Equation (5).

$\rho_{b}=\frac{M_{m}}{V_{c}}$

Where, ${ }^{P_{b}}=$ bulk density $\left(\mathrm{kg} / \mathrm{m}^{3}\right) ; M_{m}=$ mass of material $(\mathrm{kg}) ; \mathrm{V}_{\mathrm{c}}=$ volume of container $\left(\mathrm{m}^{3}\right)$

\section{Determination of angle of repose of the groundnut pods and kernels}

The angle of repose of groundnut pods and kernels was determined using the method described by (Waziri and Mittal, 1983). The groundnut pods and kernels were taken onto a circular disc with a hole that allowed the pods and kernels to fall onto a level surface via a funnel. The pods and kernels formed a freestanding cone after allowing them to settle on the level surface, as shown in Fig. 3. The cone height $(\mathrm{H})$ and diameter (D) were measured, and the angle of repose of groundnut pods and kernels was determined by the following Equation (6).

$\theta=\tan ^{-1} \frac{2 \mathrm{H}}{\mathrm{D}}$

\section{Determination of coefficient of friction of the groundnut pods and kernels}

The coefficient of friction of groundnut pods and kernels was determined using the method described by (Dutta et al., 1988). The groundnut pods and kernels were taken into a box of $160 \mathrm{~mm}$ length, $110 \mathrm{~mm}$ with and 50 $\mathrm{mm}$ height without base, and placed onto an adjustable inclined plate. The adjustable inclined plate was raised slightly until the sample box starts to slide onto the inclined plate and the inclined plate at which the sample box just begins to slide tight with the protractor through the adjustable screw, as shown in Fig. 4.

The vertical distance (P) and horizontal distance $(\mathrm{Q})$ were measured by the scale, and the coefficient of friction of groundnut pods and kernels was determined by the following Equation (7).The angle of internal friction can be measured directly by the protractor at which the sample box just starts slide on the inclined plate. 
$\mu=\tan \alpha=\frac{\mathrm{p}}{\mathrm{Q}}$

$\alpha=\tan ^{-1} \frac{\mathrm{p}}{\mathrm{Q}}$

Where, $\mathrm{P}=$ vertical distance from the fixed plate to the adjustable plate while sample box just start slide; $\mathrm{Q}=$ horizontal distance between the connection point of plates to the point when sample box just start slide and ${ }^{\alpha}=$ angle between the inclined plate and horizontal plate at which the sample box just start slide (angle of internal friction).

\section{Determination of shape of the groundnut pods and kernels}

The shape of groundnut pods and kernels was determined using the formula explained by (Abd Alla et al., 1995). It was suggested that the value of index- $\mathrm{K}>1.5$, then the grain is observed oblong, and the value of index- $\mathrm{K} \leq$ 1.5 the grain is observed spherical.

The average values of the length, width, and thickness of the groundnut pods and kernels were placed in the Equation (8), and the values of index- $\mathrm{K}$ for groundnut pods and kernels were found to be 2.96 and 1.65 , respectively.

Index $-\mathrm{K}=\frac{\mathrm{L}}{\sqrt{\mathrm{WXT}}}$

Where, $\mathrm{L}=$ length of grain $(\mathrm{mm}) ; \mathrm{W}=$ width of grain $(\mathrm{mm}) ; \mathrm{T}=$ thickness of grain $(\mathrm{mm})$

\section{Mechanical Properties of Groundnut Pods}

The unconscionable forces applied on the groundnut pods for breaking them to remove the whole kernels cause of two outcomes: (i) more damaged kernels and (ii) unbroken pods. Therefore, the rupture force's measurement is required to found out the actual force needed to break the pods without any damage to the kernels. The Universal Testing Machine (UTM) (model: UTB9052 and capacity $5 \mathrm{kN}$ ) was used to measure the rupture force at loading rate of $100 \mathrm{~mm} / \mathrm{min}$. The groundnut pods were placed on the test bench longitudinally, laterally, and vertically as shown in Fig. 5.

The applied forces on the groundnut pods were noted when the pods were placed with different orientations on the test bench. Cracking forms on the groundnut pods were analyzed when the pods placed on the test bench longitudinally, laterally, and vertically. When the groundnut pods were placed on test bench longitudinally and vertically, the longitudinally cracking occurs. Furthermore, the groundnut pods were placed on the test bench laterally, the transversely cracking occurs. The cracking forms on groundnut pods are shown in Fig. 6 for various load orientations.

\section{Determination of energy requirement to crush the groundnut pods}

The energy requirement for the crushing of groundnut pods was determined using the formula explained by (Bond, 1952).

$\mathrm{E}=0.3162 \times \mathrm{W}_{\mathrm{i}}\left(\frac{1}{\sqrt{\mathrm{L}_{\mathrm{z}}}}-\frac{1}{\sqrt{\mathrm{L}_{1}}}\right)$

Where, $\mathrm{E}=$ energy required to crush $(\mathrm{kJ} / \mathrm{kg})$, $\mathrm{W}_{\mathrm{i}}=$ work index of groundnut pods for crushing (9 to14 kWh/ton) (Gelgelo, 2016), $\mathrm{L}_{1}=$ average length of uncrushed groundnut pod $(\mathrm{mm})$ and $\mathrm{L}_{2}=$ average length of crushed groundnut kernel $(\mathrm{mm})$. The average length of groundnut pods and kernels were measured $\mathrm{L}_{1}=35.00 \mathrm{~mm}$ and $\mathrm{L}_{2}=12.12 \mathrm{~mm}$, respectively (Table 1), and the energy required to crush the groundnut pods was calculated as $\mathrm{E}=1.88$ $\mathrm{kJ} / \mathrm{kg}$. 


\section{Results and Discussion}

\section{Physical Properties of Groundnut Pods and Kernels}

The recorded physical properties of groundnut pods and kernels are given in Table 1. The average length, width, and thickness of groundnut pods and kernels were measured as $35.00,12.27,11.40 \mathrm{~mm}$ and 12.12, 7.63, 7.04respectively for TAG 24 variety of groundnuts. These measured dimensions will be beneficial in designing of hopper, the opening of the concave, crushing drum, and clearance between drum and concave unit as described by (Maduako and Hamman, 2005). The mean geometric diameter, surface area, percent sphericities, and percent aspect ratio of groundnut pods and kernels were found to be $16.93,8.65 \mathrm{~mm}$, and $906.01,237.03 \mathrm{~mm}^{2}$ and 48.95, 71.94\% and 35.71, 63.74\%, respectively. The percentage sphericity of groundnut kernels was observed higher than the groundnut pods, which means the sliding ability of kernels is higher than that of the pods. The bulk density and average weight of one thousand groundnut pods and kernels were measured as $289.54,622.43 \mathrm{~kg} / \mathrm{m}^{3}$, and $1290.5 \mathrm{~g}, \quad 629.57 \mathrm{~g}$, respectively. The measured bulk density and the average weight of groundnut pods and kernels will be used to decide the size and capacity of hopper and crushing chamber that provide the stability of the machine during operation. The angle of repose and coefficient of friction of the groundnut pods and kernels were found to be $24.20^{\circ}, 20.43^{\circ}$, and $0.41,0.43$, respectively. It was observed that the angle of repose for groundnut pods was more than the kernels, and this may be due to the irregular and roughness surface of the groundnut pods. The conical structure of groundnut pods was raised by stick the pods one another, and it made a larger angle than kernels. The static coefficient of groundnut pods and kernels is needful in designing storage bins, pneumatic conveyor systems, screw conveyors, and threshing (Sahay and Singh, 2003). These measured physical properties of groundnut pods and kernels may be slightly deviate from the other physical properties of groundnut pods and kernels explained by Muhammad et al., (2015), Odesanya et al., (2015).

Table.1 Physical properties of groundnut pods and kernels

\begin{tabular}{|c|c|c|c|c|c|}
\hline \multirow[t]{2}{*}{ Properties } & \multirow{2}{*}{$\begin{array}{c}\text { No. of } \\
\text { Samples }\end{array}$} & \multicolumn{2}{|c|}{ Mean Value } & \multicolumn{2}{|c|}{ Standard Deviation } \\
\hline & & Pods & Kernels & Pods & Kernels \\
\hline Length (mm) & 100 & 35.00 & 12.12 & \pm 4.87 & \pm 1.56 \\
\hline Width (mm) & 100 & 12.27 & 7.63 & \pm 1.03 & \pm 0.73 \\
\hline Thickness (mm) & 100 & 11.40 & 7.04 & \pm 0.84 & \pm 0.81 \\
\hline Geometric mean diameter (mm) & 100 & 16.93 & 8.65 & \pm 1.26 & \pm 0.79 \\
\hline Surface area $\left(\mathrm{mm}^{2}\right)$ & 100 & 906.01 & 237.03 & \pm 133.71 & \pm 43.31 \\
\hline Sphericity (\%) & 100 & 48.95 & 71.94 & \pm 4.81 & \pm 6.41 \\
\hline Aspect ratio (\%) & 100 & 35.71 & 63.74 & \pm 5.62 & \pm 7.99 \\
\hline Bulk density $\left(\mathrm{kg} / \mathrm{m}^{3}\right)$ & 5 & 289.54 & 622.43 & \pm 22.65 & \pm 16.54 \\
\hline Groundnut sample weight (g) & 1000 & 1290.50 & 629.57 & \pm 32.29 & \pm 20.63 \\
\hline Moisture content $(\%, \mathrm{db})$ & 5 & 6.82 & 5.02 & \pm 0.45 & \pm 0.53 \\
\hline Angle of repose pods $\left({ }^{\circ}\right)$ & 5 & 24.20 & 20.43 & \pm 1.87 & \pm 1.56 \\
\hline Coefficient of friction & 5 & 0.41 & 0.43 & \pm 0.001 & \pm 0.002 \\
\hline Shape & & & Oblong & & \\
\hline
\end{tabular}


Table.2 Rupture force of groundnut pods with different loading orientation

\begin{tabular}{|l|c|c|c|c|c|c|}
\hline \multirow{2}{*}{$\begin{array}{l}\text { Loading } \\
\text { orientation }\end{array}$} & \multicolumn{3}{|c|}{ Rupture force (N) } & \multicolumn{3}{c|}{ Compressive extension (mm) } \\
\cline { 2 - 7 } Longitudinally & Max. & Min. & Mean & Max. & Min. & Mean \\
\hline Laterally & 250.86 & 37.27 & 62.37 & 3.58 & 1.99 & 2.26 \\
\hline Vertically & 43.41 & 250.02 & 250.21 & 6.70 & 4.73 & 5.33 \\
\hline
\end{tabular}

Fig.1 Measurement of principal dimensions ( $\mathrm{mm}$ ) of groundnut pods

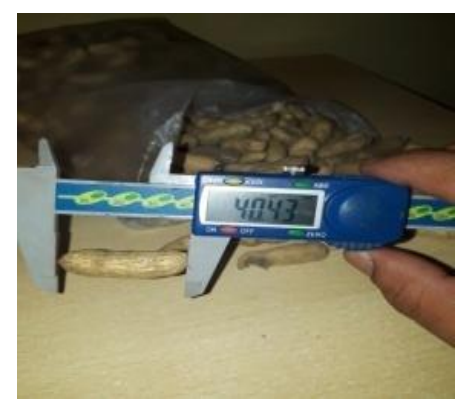

(a) Length

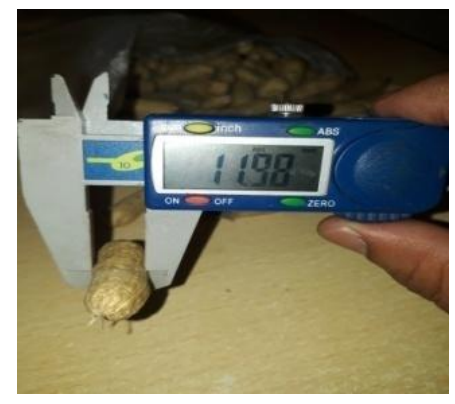

(b) Width

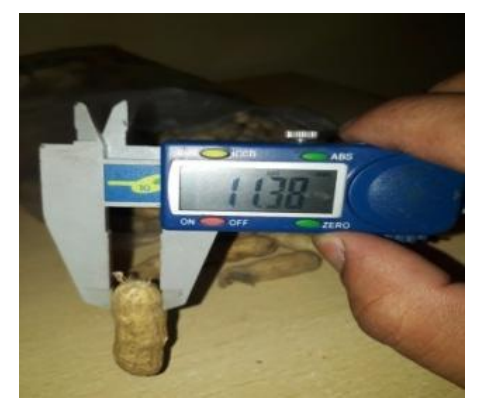

(c)Thickness

Fig.2 Measurement of principal dimensions ( $\mathrm{mm}$ ) of groundnut kernels

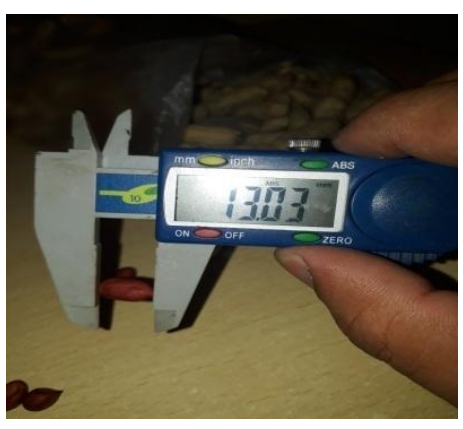

(a) Length

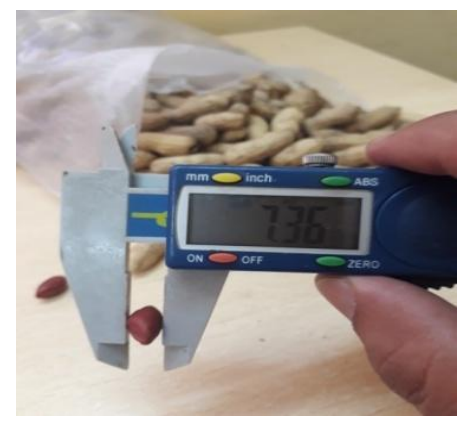

(b) Width

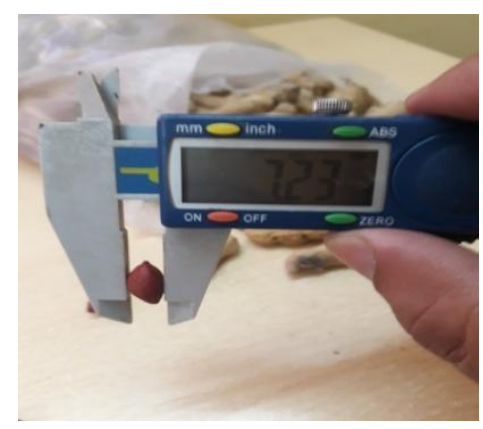

(c) Thickness

Fig.3 Measurement of angle of repose of groundnut pods and kernels

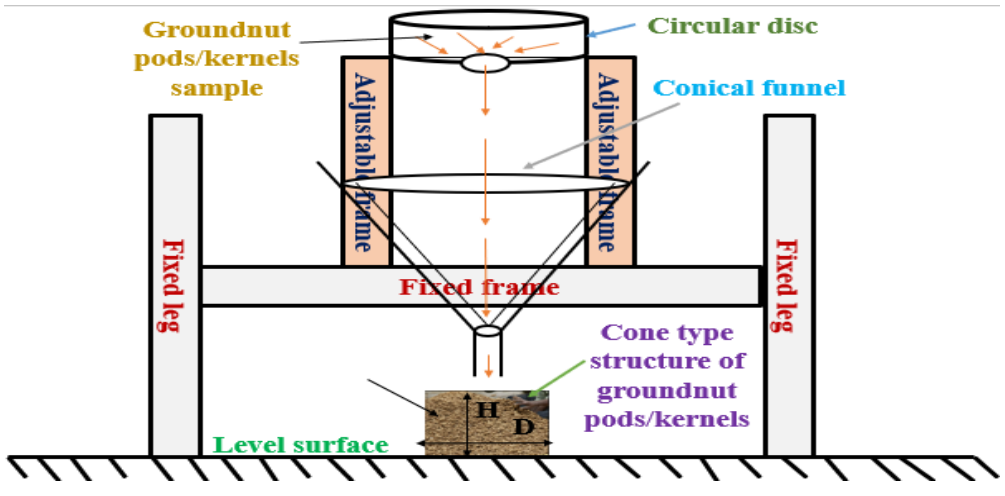


Fig.4 Inclined plate apparatus for measurement of coefficient of friction

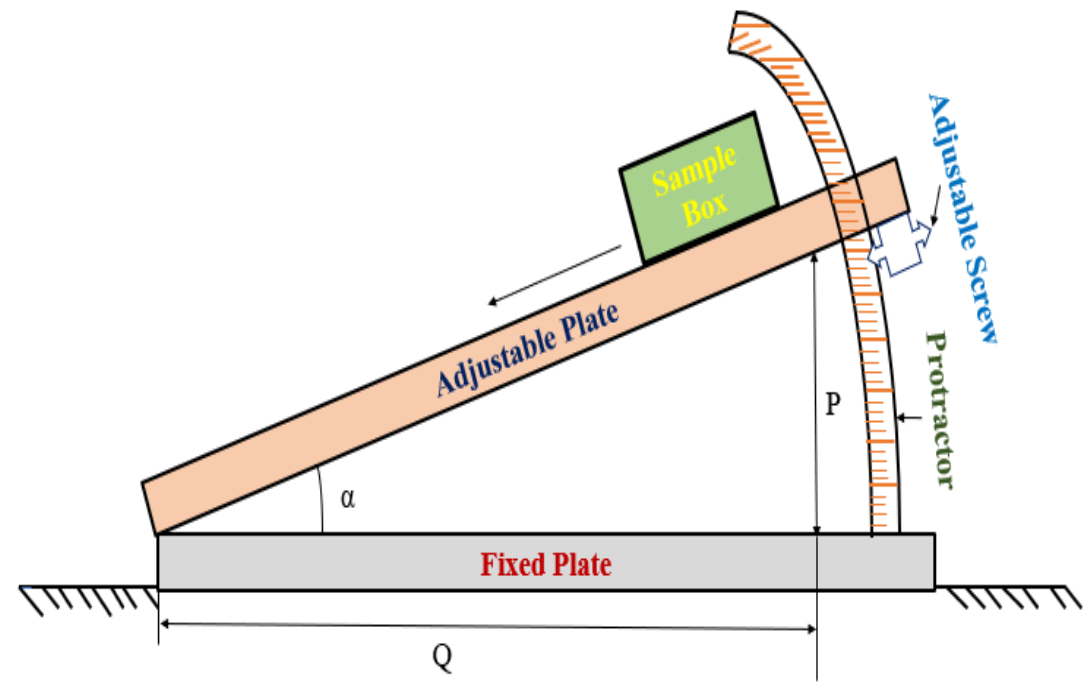

Fig.5 Rupture force measurement of groundnut pods on UTM

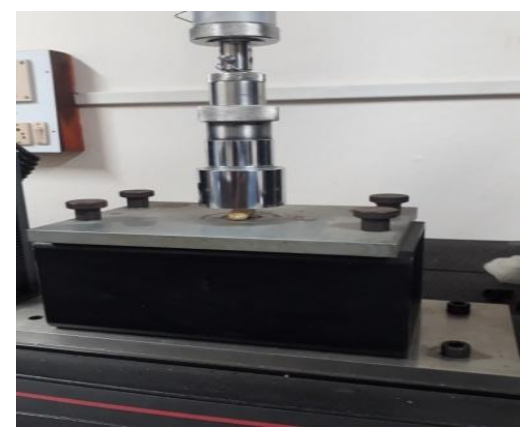

(a) Longitudinally

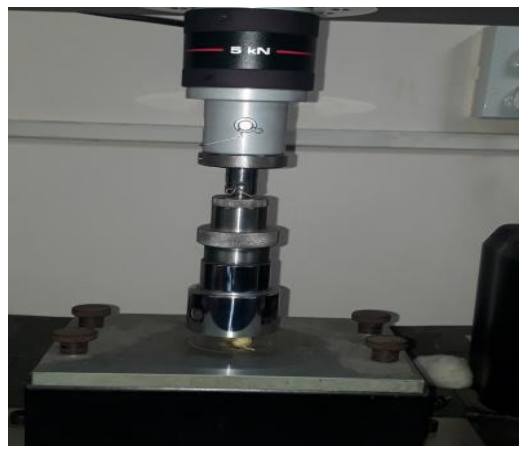

(b) Laterally

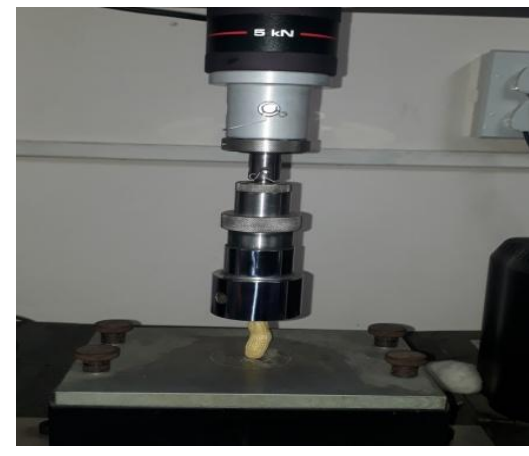

(c) Vertically

Fig.6 Cracking forms on groundnut pods with various loading orientation

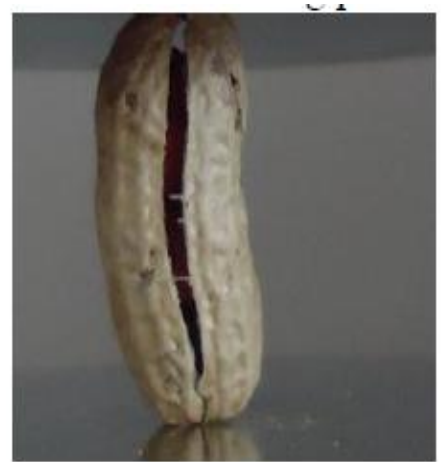

(b) Longitudinally

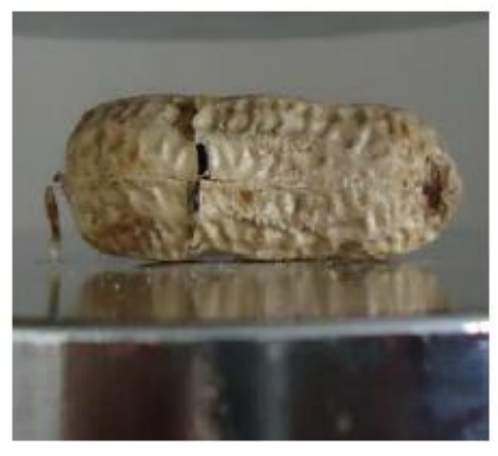

(b) Laterally

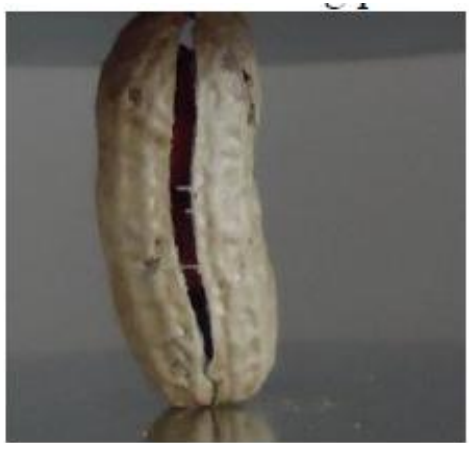

(c) Vertically 
Fig.7 Rupture force measurement by UTM
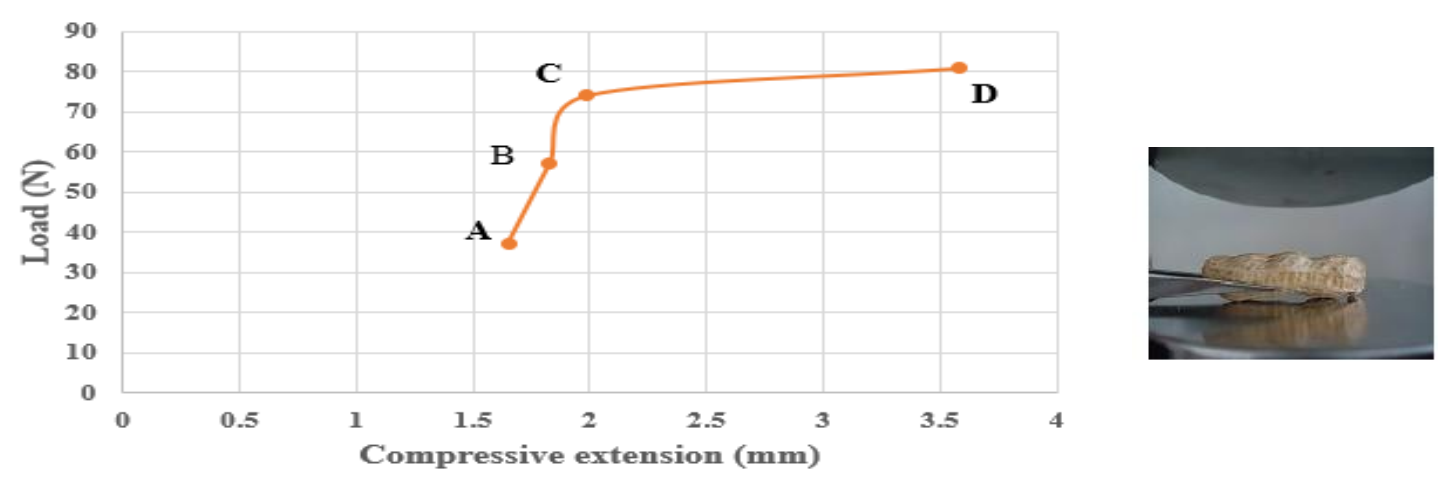

(a) Longitudinally orientation
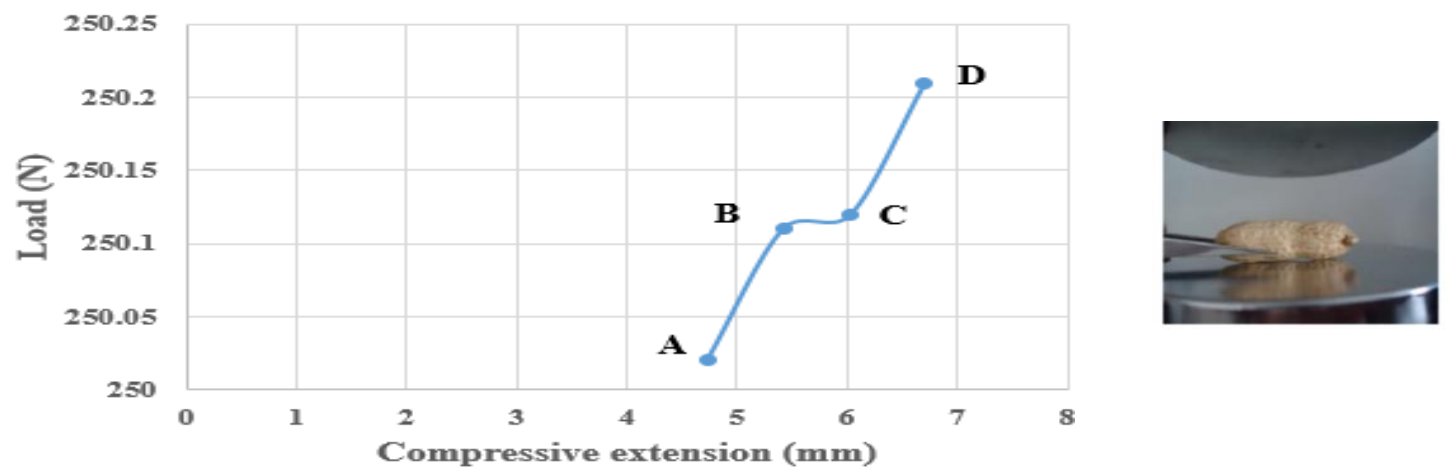

(b) Laterally orientation
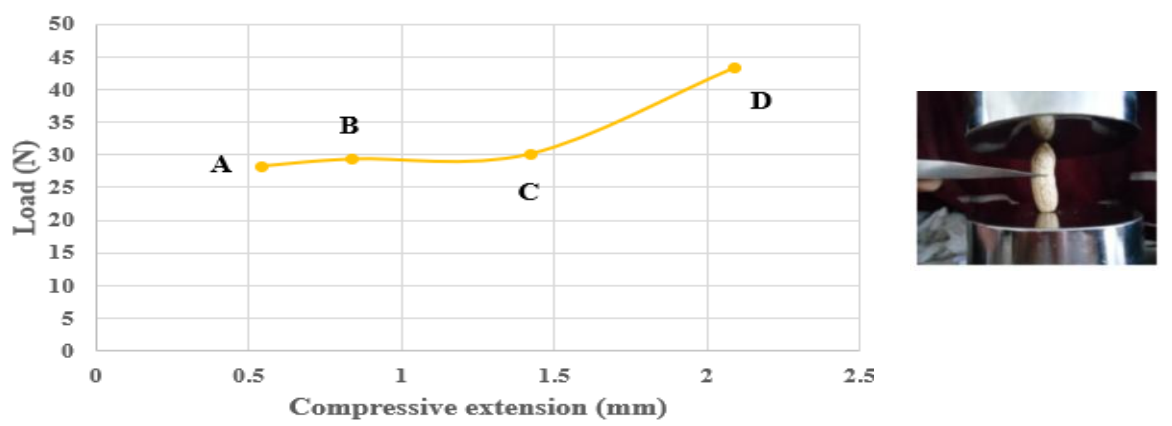

(c) Vertically orientation

\section{Mechanical properties of groundnut pods}

The mechanical properties of groundnut pods also discussed, and the rupture force measured by the UTM machine is given in Table 2. The load-compressive extension graphs of longitudinally, laterally, and vertically are shown in Fig. 7 (a), (b) and (c). When the groundnut pods placed on the test bench longitudinally, laterally and vertically, the rupture force graph initially obtained a straight line, as shown in graphs A-B line. This A-B line follows the Hook's law. Beyond point $\mathrm{B}$, the load increased by the UTM machine; elasticity of the groundnut pod surface is proceeded; thus, the surface of groundnut pod is supposed to be viscous. Due to the increasing load, the linearity of the 
curve changed, as shown in the graphs B-C curve. At point $\mathrm{C}$, the surface of groundnut pod leaks and the void space was removed; hence, resulting in a sudden variation in the curve. After that point, $\mathrm{C}$, a continuous loading on the groundnut pod outcomes in rupture of the groundnut pod at point D. Therefore, the point D in graphs represents the cracking force required to remove the kernels from groundnut pods. The mean rupture forces were measured to be 62.37 , 250.21, and $32.74 \mathrm{~N}$ at $6.28 \%(\mathrm{db})$ moisture content with different loading orientations, such as longitudinally, laterally, and vertically, respectively. The maximum and minimum rupture forces were noted as 80.86 and $37.27 \mathrm{~N}, 250.21$ and $250.02 \mathrm{~N}, 43.41$, and $28.19 \mathrm{~N}$ in longitudinally, laterally, and vertically orientation, respectively, as shown in Fig. 7. It could be analyzed that the highest rupture force required, when the load applied along with the laterally orientation and minimum in the vertically orientation. These rupture forces were useful to decide the power consumption to break the groundnut pods. These measured rupture forces may be slightly deviate from the other rupture forces explained by (Aydin, 2007; Muhammad et al., 2015). It may be due to the groundnut variety and agronomic conditions of the crop. The energy required to crush the groundnut pods was determined as $1.88 \mathrm{~kJ} / \mathrm{kg}$ for particular TAG-24 groundnut variety.

In conclusion the physical and mechanical properties of groundnut pods and kernels are fundamental parameters that provide a brief knowledge and useful to design the agriculture machine in harvesting, threshing, shelling, and post-harvest processing operation. The measured physical properties and rupture force to remove the kernels from the groundnut pods depend on the groundnut variety and agronomic conditions of the crop. These mechanical properties of groundnut pods at different loading orientations are superior important in designing of milling, handling, storage, and transportation unit. Lack of knowledge of mechanical properties might lead to more breakage of kernels in processing operations, causing minimum germination rate and increasing the chances of inset and pest infection of the quality of the final product.

\section{Acknowledgements}

This study was conducted at the Agricultural and Food Engineering Department, Indian Institute of Technology, West Bengal, India. I would like to express my heartfelt gratitude and sincere thanks to my supervisor Dr. Rajendra Machavaram (Assistant Professor), for his excellent guidance, academic and moral support throughout the research work.

\section{Conflict of interest}

The authors declare that there are no conflicts of interest.

\section{References}

Agrawal, K. K., Clary, B. L., and Schroeder, E. W. (1973). Mathematical models of peanut pod geometry. Transactions of the ASAE. 16(2): 315-319.

AOAC (1980). Official methods of analysis, $13^{\text {th }}$ edition. Association of official analytical chemists, Washington, D.C. 376-384.

ASAE (1983). ASAE standard S352, moisture measurement-grains and seeds. Agricultural Engineers year book. American Society of Agricultural Engineers. St. Joseph, Michigan.

Abd Alla, H. S., Randwan, S. M., and ElHanafy, E. H. (1995). Effect of some physical properties of rice grain on milling quality. Misr Journal of Agricultural Engineering. 12(1): 143155. 
Akcali, I. D., Ince, A. H. M. E. T., and Guzel, E. M. İ. N. (2006). Selected physical properties of peanuts. International Journal of Food Properties. 9(1): 2537.

Aydin, C. (2007). Some engineering properties of peanut and kernel. Journal of Food Engineering. 79(3): 810-816.

Anonymous (2018). Ministry of Agriculture \& Farmers Welfare, Government of India, New Delhi. Directorate of Economics and Statistics. http://agricoop.gov.in/sites/default/files /agristatglance2018.pdf

Bond, F.C. (1952). The third theory of comminution. Transactions on AIME Mining Engineering. 193: 484-494.

Dutta, S. K., Nema, V. K., and Bhardwaj, R. K. (1988). Physical properties of gram. Journal of Agricultural Engineering Research. 39(4): 259-268.

Davies, R. M. (2009). Some physical properties of groundnut grains. Research Journal of Applied Sciences, Engineering and Technology. 1(2): 10-13.

Gelgelo, K. (2016). Design and development of groundnut sheller. International Journal of Engineering Research. 4(2): 223-233.

Kaleemullah, S. (1992). The effect of moisture content on the physical properties of groundnut kernels. Tropical science. 32(2): 129136.

Koushkaki, H. R., Moghadami, A. N., Zare, D., and Karimi, G. (2017). Experimental and theoretical investigation of hot air-infrared thin layer drying of corn in a fixed and vibratory bed dryer. Engineering in agriculture, environment and food. 10(3): 191-197.

McCabe, W. L., Smith, J.C., and Harriot, P. (1986). Unit Operations of Chemical
Engineering. New York: McGraw-Hill. 5: 154 .

Mohsenin, N. N. (1986). Physical properties of plant and animal materials. Gordon and Breach Science Publishers, New York. No. 581.1 M 64.

Manuwa, S. I., and Afuye, G. G. (2004). Moisture dependent physical properties of soyabean (Var-TGx 18715E). Nigerian Journal of Industrial and Studies. 3(2): 45-54.

Maduako, J. N., and Hamman, M. (2005). Determination of Some Physical Properties of Three Groundnut Varieties. Nigerian Journal of Technology. 24(2): 12-28.

Muhammad, A. I., Isiaka, M., Fagge, A. A., Attanda, M. L., Lawan, I., and Dangora, N. D. (2015). Some engineering properties of three varieties of groundnut pods and kernels. Arid Zone Journal of Engineering, Technology and Environment. 11: 61-75.

Olajide, J. O., and Igbeka, J. C. (2003). Some physical properties of groundnut kernels. Journal of food engineering. 58(2): 201-204.

Okello, D. K., Biruma, M., and Deom, C. M. (2010). Overview of groundnuts research in Uganda: Past, present and future. African Journal of Biotechnology. 9(39): 6448-6459.

Odesanya, K. O., KA, A., and TAO, S. (2015). Estimation of Engineering Parameters for the Development of a Groundnut Decorticator. International Journal of Novel Research in Engineering and Applied Sciences. 2(1): 2-25.

Putnam, D. H., Oplinger, E. S., Teynor, T. M., Oelke, E. A., Kelling, K. A. and Doll, J. D. (2013). Alternative Field Crops Manual. Peanut.

Razari, M. A., Emadzadeh, B., Rafe, A., and Mohammed, A. A. (2007). The 
physical properties of pistachio nut and its kernel as a function of moisture content and variety, part 1 Geometric properties. Journal of food engineering. 81: 209-217.

Singh, G., and Thongsawatwong, P. (1983). Evaluation and modification of two peanut shellers. AMA, agricultural mechanization in Asia, Africa and Latin America. 14(3): 33-40.

Sahay, K. and Singh, K. K. (2003). Unit Operations of Agricultural Processing (2nd ed. Revised). New Delhi: Vikas Publishing House PVT LTD.

Shubham, D. (2015). Design and fabrication of groundnut pod separating machine. Journal of Recent Research in Civil and Mechanical Engineering. 2(2): 147-150.

Waziri, A. N., and Mittal, J. P. (1983). Design-related physical properties of selected agricultural products. Agricultural mechanization in Asia, Africa and Latin America.14: 59-62.

\section{How to cite this article:}

Vinod Choudhary, Rajendra Machavaram, Vikas and Ravi Shankar Singh. 2020. Engineering Properties of Groundnut Pods and Kernels: A Key Role for Designing the Post-harvest Processing Equipment. Int.J.Curr.Microbiol.App.Sci. 9(08): 1751-1761.

doi: https://doi.org/10.20546/ijcmas.2020.908.202 